\title{
USE OF LEARNING MANAGEMENT SYSTEM ILIAS IN TEACHING TECHNOLOGIES FOR INTENDING TEACHERS OF SECONDARY AND VOCATIONAL EDUCATION
}

\author{
Iryna Shymkova \\ Vinnytsia Mykhailo Kotsiubynskyi State Pedagogical University, Ukraine \\ Svitlana Tsvilyk \\ Vinnytsia Mykhailo Kotsiubynskyi State Pedagogical University, Ukraine \\ Vitalii Hlukhaniuk \\ Vinnytsia Mykhailo Kotsiubynskyi State Pedagogical University, Ukraine \\ Viktor Solovei \\ Vinnytsia Mykhailo Kotsiubynskyi State Pedagogical University, Ukraine \\ Volodymyr Harkushevskyi \\ Vinnytsia Mykhailo Kotsiubynskyi State Pedagogical University, Ukraine
}

\begin{abstract}
The purpose of the article is to substantiate the features of e-learning technologies of materials for intending teachers of secondary and vocational education through the use of available learning management system ILIAS.

The web-based learning management system ILIAS is used to develop e-learning materials, manage and disseminate multimedia materials in an online educational environment. The ILIAS system is available, free of charge and designed to manage learning resources as part of integrated systems and e-learning. The independence of the international project ILIAS and its support by many European universities as well as IT organizations are the basis for use and development in the training of intending teachers of secondary and vocational education. While researching the given issue, we have used theoretical and empirical research methods, i.e. analysis and synthesis to clarify the basic concepts and categories of computer-based education; conceptual and comparative analysis of curricula and programs, psychological and pedagogical, scientific and methodical literature as well as the materials of scientific and practical conferences on the problem of research and advanced pedagogical experience, comparing traditional and computer-oriented approaches in teaching technology. We have also used the methods of identifying patterns and drawing conclusions on the given issue.

The use of web-based management system ILIAS in the teaching of construction materials technology contributes to the formation of professional competencies of intending teachers of secondary and vocational education, manifested in the ability to integrate knowledge of different technologies, make sound technical decisions and implement them in virtual reality; selection of technological processes, planning, forecasting and evaluation of technology efficiency; perception of computer models of technological processes.

Keywords: construction materials technology, e-learning, pedagogical software, intending teachers of secondary and vocational education, modern technological processes, computer testing.
\end{abstract}




\section{Introduction}

Computer technology is widely used in modern education. The intensification of the educational process is nowadays linked to the development of both individual courseware and complex learning computer systems (LCS). The Paris Communiqué Paris recommendations for 2018 state that higher education institutions (HEIs) should prepare students and guide teachers so that they act actively and creatively in digital environments with advanced data analysis, using e-learning and blended learning to build digital skills and personal competences. In this process, intelligent NQSs are a new type of learning system, capable of supporting and monitoring student learning at different levels of complexity in an individualised way and providing each student with opportunities to acquire new knowledge as quickly and efficiently as possible.

The report of the COMPETING project, funded by the European Union Erasmus ${ }^{+}$programme, outlines the didactic and technical concepts as a basis for course design, development of learning materials and digital tools to support the educational process in new courses/curricula. The purpose of the COMPETING project is to create a blended modular learning environment for specialist training by integrating advanced technological solutions. Part of the project is the Learning Management System (LMS) (FHOO, 2020) which is a selfcontained program where materials (instruction) can be placed. The system makes it possible to organise these materials (Gatreau, 2011). At the same time, such a system serves to introduce various digital tools in education, and the system is also used to manage teaching and learning activities in an online learning environment (Dias \& Diniz, 2014).

The analysis of selected studies by scientists on the problems of implementation of electronic (digital) learning (Alabi, Thaddeus, \& Falode, 2020; Brusilovsky \& Miller, 1999) allows us to consider a promising direction of improvement and computerisation of the educational process in HEIs through the introduction of complex software solutions - Learning Management Systems (LMS) for creating an electronic information learning environment, learning management, development, organisation, placement of electronic learning materials, administration of learning resources, tracking progress of learning activities by students and evaluating their results.

The implementation of such systems in educational institutions worldwide through commercial software products (e.g. WebCT, Blackboard, HyperMethod eLearning Server) and free and open source software (e.g. Moodle, ILIAS, etc.), reflected in scientific publications (Osman, 2010), shows that e-learning has the features of an adapted technology of interaction with the student in real time, 
providing individual automated support to each participant of the educational process, can be effective in achieving programme learning outcomes.

Thus, the New Media Consortium report "NMC Horizon: Higher Education 2017" focuses on the following advances in educational technology for higher education: adaptive learning technologies, mobile learning, Internet of Things, next generation learning management systems, artificial intelligence, natural user interfaces. The development of personalised learning, linked to learning analytics, in an adaptive learning environment is based on technologies to track student progress and use data to make real-time adjustments to the teaching process (Adams et al., 2017, p. 38).

The study of the literature we have used allows us to state that automated learning management systems (LMS), built using information and telecommunication technologies, are widely used in modern conditions by students and teachers alike. LMS ILIAS is successfully used in the most developed countries of the world (ILIAS Installations) because it provides many advantages: it is available anywhere and anytime; it allows the use of various modern tools and teaching methods (text, multimedia, tests, etc.); it enables students to communicate with each other and teachers online; the simultaneous use by students of many sources of educational information; the use in the learning process of new information technology advances that contribute to a person's entry into the global information and education space and the formation of information and digital competence.

\section{Research Methodological Foundations and Methods}

The idea of using didactic (teaching and learning) complexes - sets of scientific, methodological and information materials for the organization of the learning process in a particular discipline is now common in academia and in the practice of higher education institutions (HEIs). Scientific research into the creation and use in the educational process of electronic educational and methodical complexes, as well as psychological and pedagogical justification of the specifics of the use of information and communication technologies (ICT) for this purpose prove that the introduction of eLMK and ICT in the educational process opens up new opportunities for deepening and expanding the theoretical knowledge base and enhancing the learning and cognitive activities of students, creating conditions for individualized learning of intending teachers of technology in secondary and vocational education institutions.

With the increasing role of students' independent work and the introduction of new forms of educational process organization, to which we include elearning, the function of the teacher as a source of information loses its relevance - he/she becomes, above all, an organizer, consultant, supervisor and 
expert of learning, cognitive activities and independent work of students. These aspects determine the search for innovative means of monitoring the quality of education, determining the effectiveness of a particular educational process and the students' skills during the monitoring activities in the learning of certain disciplines. Optimal organization of the e-learning process is possible under conditions of flexible management with the teacher-student feedback system, when teachers are provided with information about the degree of coincidence of the actually performed action and the planned action. The effectiveness of feedback is achieved by systematic, regular, consistent monitoring and in the context of certain methods that do not require a significant amount of study time for students to complete assignments and for the teacher to check them. This is what an automated test form of monitoring in an e-learning environment is all about.

At the turn of the 20th-21st centuries, scientists, educators, and IT specialists are acutely interested in the content and methods of computer-based knowledge control: different types of control are being studied (Lerner, 1996); types of questions, their components, and metadata are being usually used in forming the content and set of control tasks (Brusilovsky \& Miller, 1999); mathematical methods of knowledge evaluation (Moiseev, Usmanov, Tarantseva, \& Piatyrublevii, 2001) along with modern control technologies are being worked out. However, it is worth mentioning the lack of special scientific research that would deal with the problems of organizing a system of computer monitoring of independent cognitive activity of future teachers of secondary and vocational education students in learning technologies that would enhance the effectiveness of e-learning and the formation of students' abilities to work independently.

Scholars claim that e-learning and systematic objective monitoring are effective means of differentiating, individualising and increasing students' motivation for systematic self-learning. Students take an active part in organizing and carrying out their learning and cognitive activities by selfmonitoring and self-checking through testing their independent work. It is worth agreeing with V. Kuzneczov, "self-testing with diagnostic tests is of great psychological importance, it stimulates learning» (Kuzneczov, 1999).

The advantages of testing as a tool for assessing the effectiveness of e-learning compared to other forms of monitoring are, firstly, that the tests are qualitative and objective means of assessment and, secondly, that the test indicators focus on measuring and determining the levels of mastering key concepts, the content of topics and curriculum sections, the formation of general and professional subject competences of students, rather than stating whether a student has a certain set of formal mastered knowledge, which is indicated by Majorov (Majorov, 1997). 
In our study we also considered the advantages of computer-based testing over traditional forms of knowledge control (Avanesov, 2002): fast results and freeing the teacher from the time-consuming work of processing the tests; objective assessment; computer-based testing is more interesting than traditional forms of questioning and creates positive motivation among students as well as increases effectiveness of the teaching staff.

In scientific literature the problems of e-learning and automated (computerbased) monitoring of students' knowledge, we examine in the aspect of technology training for future teachers of secondary and vocational education, have two interrelated aspects - methodological and technical (Table 1) (Zajceva, Prokof'eva, 2002).

Table 1 Methodological and Technical Aspects of E-learning and Computer-based Student Monitoring

\begin{tabular}{|l|l|}
\hline \multicolumn{1}{|c|}{ Methodological aspect } & \multicolumn{1}{c|}{ Technical aspect } \\
\hline $\begin{array}{l}\text { 1. Designing the content and teaching } \\
\text { techniques. }\end{array}$ & $\begin{array}{l}\text { 1. Automatically generated set of checklists } \\
\text { based on the selected approach. }\end{array}$ \\
$\begin{array}{l}\text { 2. Planning and organization of monitoring } \\
\text { activities. }\end{array}$ & $\begin{array}{l}\text { 2. Selection and use of different settings in the } \\
\text { monitoring system. }\end{array}$ \\
$\begin{array}{l}\text { 3. Identifying the types of questions and } \\
\text { selecting the tasks for testing the students' } \\
\text { knowledge. }\end{array}$ & $\begin{array}{l}\text { 3. } \begin{array}{l}\text { 3. Defining algorithms for assessing } \\
\text { knowledge and determining the levels of } \\
\text { formation of subject competences and the } \\
\text { like. }\end{array} \\
\begin{array}{l}\text { 4. Generating a set of questions and } \\
\text { assignments for the survey. }\end{array} \\
\begin{array}{l}\text { 5efining the criteria for assessing the } \\
\text { performance of a particular task and of the } \\
\text { checklist as a whole, and so and so forth. }\end{array}\end{array}$ \\
\hline
\end{tabular}

Modern computer-based test control tools enable the use of different forms of test tasks, adaptation to the user's capabilities, generation of a given sequence of tasks from a common database, web-based interface of software shells intuitive and easy to use on different devices (Chua, Yan Piaw, 2012).

While working on the learning technology content for future teachers of secondary and vocational education institutions and creating tests, we were inspired by the scientists' recommendations, (Avanesov (2002), Kuzneczov (1999), Majorov (1997) and others), who proved that the main conditions necessary for organizing an effective automated test monitoring are: a) consideration of classical and modern test theory, which ensures reliability, validity and effectiveness of control; b) test control is not limited by testing students' knowledge; c) in the testing process, a comprehensive check of student's learning activity, in particular: dynamics of general development, formation of general and professional competencies, activity, cognitive interests, 
creative abilities of future teachers, is especially important; d) a creative teacher has creative attitude to organize and manage the educational process.

We took into consideration Avanesov's opinion that "tests can be effective only in an educational process in which the teacher ... becomes a developer of a new software and methodological tools, an organizer of the process of students' independent learning. «Training should begin with an entry test, be followed by self-monitoring and end with a final test» (Avanesov, 2002). For this reason, our practice involves the active participation of students in the organization and implementation of cognitive activities through self-monitoring by means of testing of their learning results.

\section{Results and Discussion}

In order to improve the efficiency of the students' self-study activities we have used ILIAS, a free and open-source web-based system for teaching construction materials technology. On the basis of ILIAS the electronic course «Material science and production technology of structural materials» was created and implemented into the educational process (Fig. 1) as well as the system of computer-based knowledge monitoring and measuring the levels of students' learning achievements has been developed.

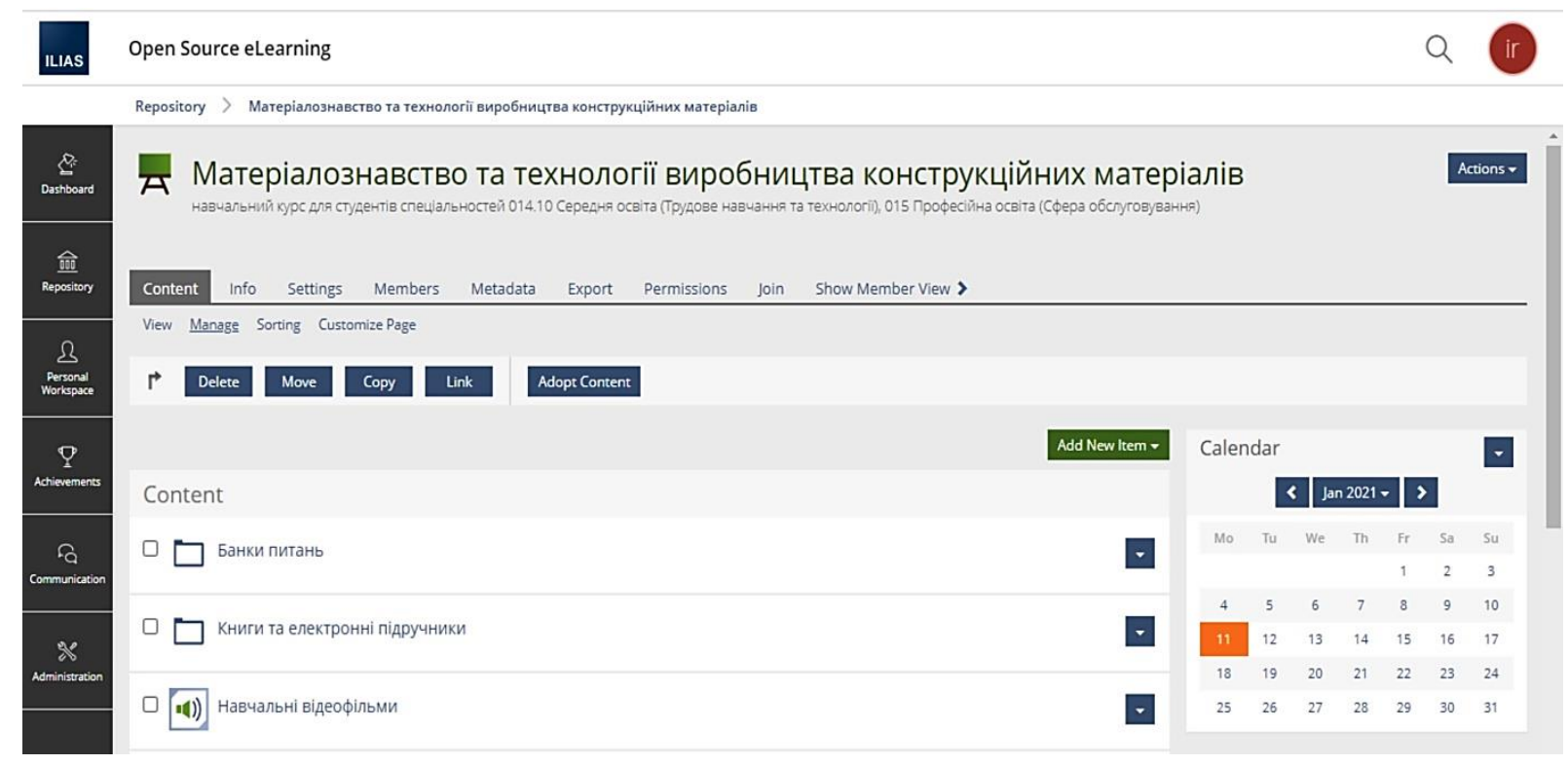

Figure 1 Interface of the E-learning Course «Material Science and Manufacturing Technology for Structural Materials» 
We agree with scholars that using the ILIAS learning platform can turn any boring or complex learning content into interesting and easy to understand (Alabi et al., 2020).

ILIAS provides the opportunity not only to implement the learning content of construction materials technology, but also to connect virtual classrooms and evaluate students' progress. At the same time, students can study course content at any accessible location, check assessments, create and develop learning materials (Fig. 2).

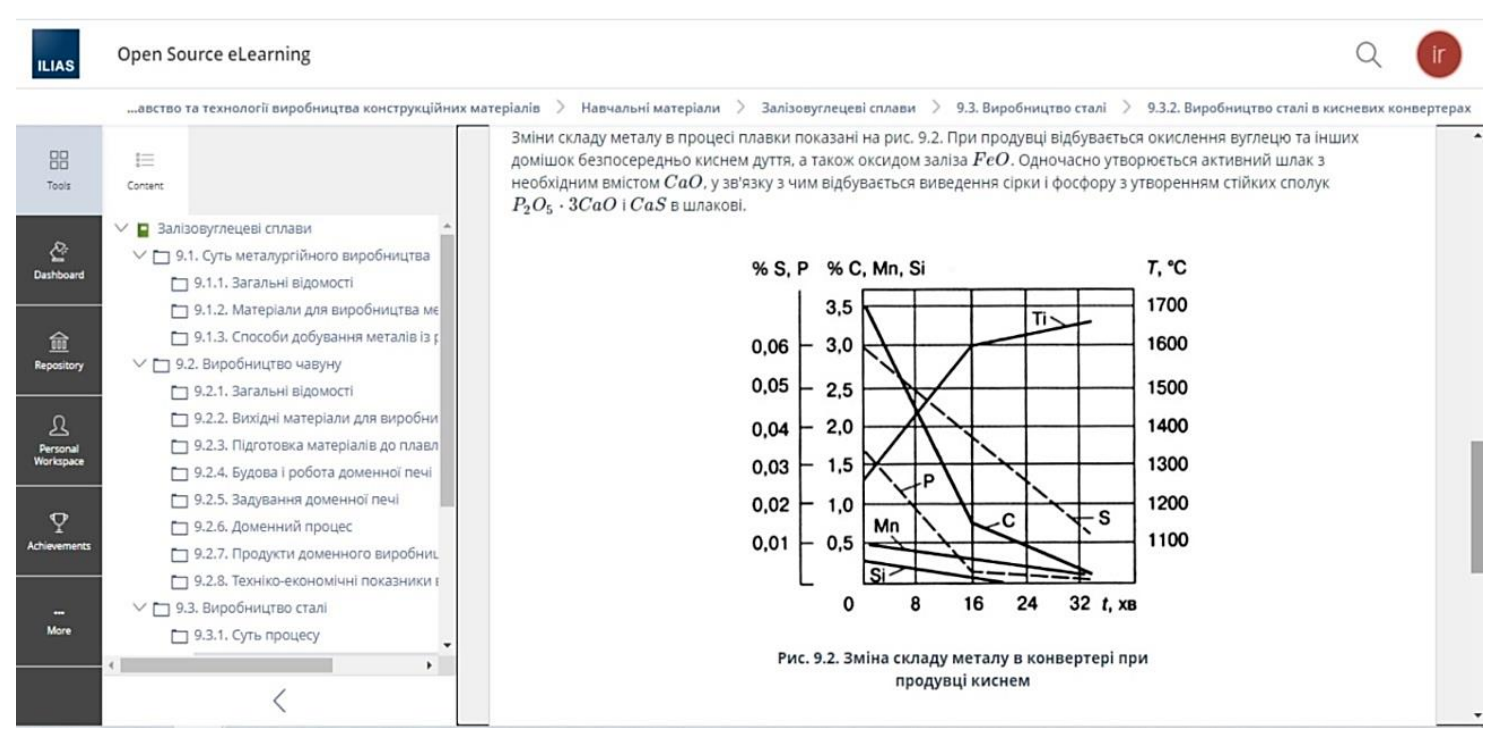

Figure 2 Fragment of the Contents of the E-course «Material Science and Manufacturing Technology of Structural Materials»

We have used ILIAS to develop, manage and distribute multimedia learning materials. The training materials were created for online learning environments with the following considerations in mind (Shymkova, 2012):

1. A single hardware and software platform consisting of individual, functionally complete subsystems with a high degree of integration makes it possible to provide a holistic, integrated solution. In particular, it is possible to monitor and support the development and implementation of the training and information provision process centrally.

2. The implementation of the system reflects the experience of its many years of use in education. In addition, the stable development cycle, prompt implementation of the latest information technology (IT) trends and professional support of the software product are important advantages. The implementation of the developed professional-level platform in compliance with international standards seems to us more convenient and logical than the common practice of combining software and multimedia products created by teachers (or students) 
themselves using different tools and data formats.

3. Simple yet effective unified tools for creating and publishing web-based multimedia learning resources, supporting a wide variety of multimedia formats (TeX, audio, video, media streaming formats), allow users with varying levels of IT competency, from basic to professional, to work effectively with the system.

4. Integrated monitoring tools allow you to keep track of every user and item of learning material, see detailed access statistics and monitor the progress of pre-defined tasks set by the teacher.

5. A powerful test control system supports various types of questions from classical correct answer selection tasks to open-ended questions with uncertain answer analysis (Levenshtein algorithm) and multimedia data in the tasks, has a flexible evaluation and results processing system.

6. Integrated information security features - centralised authentication, authorisation and logging of incoming requests, remote access, separation of access rights and the ability to personalise the working environment.

7. Low cost of use and implementation. The software package is free, independent of the operating system, and any modern web browser is sufficient to use it as a user.

8. A priori, the system is oriented towards network use. Implemented on its basis, electronic-methodical training complex (EMTC) can be used in the local network for information and methodological support of students' independent activities, creation of automated test control centres, organization of educational environment for electronic and distance learning of higher education institutions.

ILIAS built-in test controls allow for online testing and automatic processing of results, i.e. ILIAS test tasks have advanced interactive controls with error diagnostics and feedback. ILIAS uses the following test tasks: Multiple Choice Question (Single Response) with multiple correct answers (Multiple Choice Question - Multiple Response). Multiple Response) Matching Question (Matching Question) Sequencing Question (Ordening Question) Cloze Question (Text Subset Question) Short Text Answer (Essay Question) Interactive Image with Active Slices (Image Map Question) Numerical Value or Spacing Check (Numeric Question).

In order to receive access to ILIAS, a user account should be registered, a unique identifier (login) and password are provided which will be used every time the student logs in to the system. For example, either an account is created independently by using the link on the home page, or a teacher registers student, signs them up for a particular course and then issues logins and passwords (which the student can later change), controls the content and amount of information available to the student group.

Test assignments are stored in test databanks and can be used in various tests, training courses, and combinations. Separately, test assignments integrated 
directly into a block of training material - ILIAS training module - are offered to check comprehension and self-monitoring of learnt material. The ILIAS test can be implemented as a separate learning object in the repository by clicking on a specific header to access the test (Fig. 3).

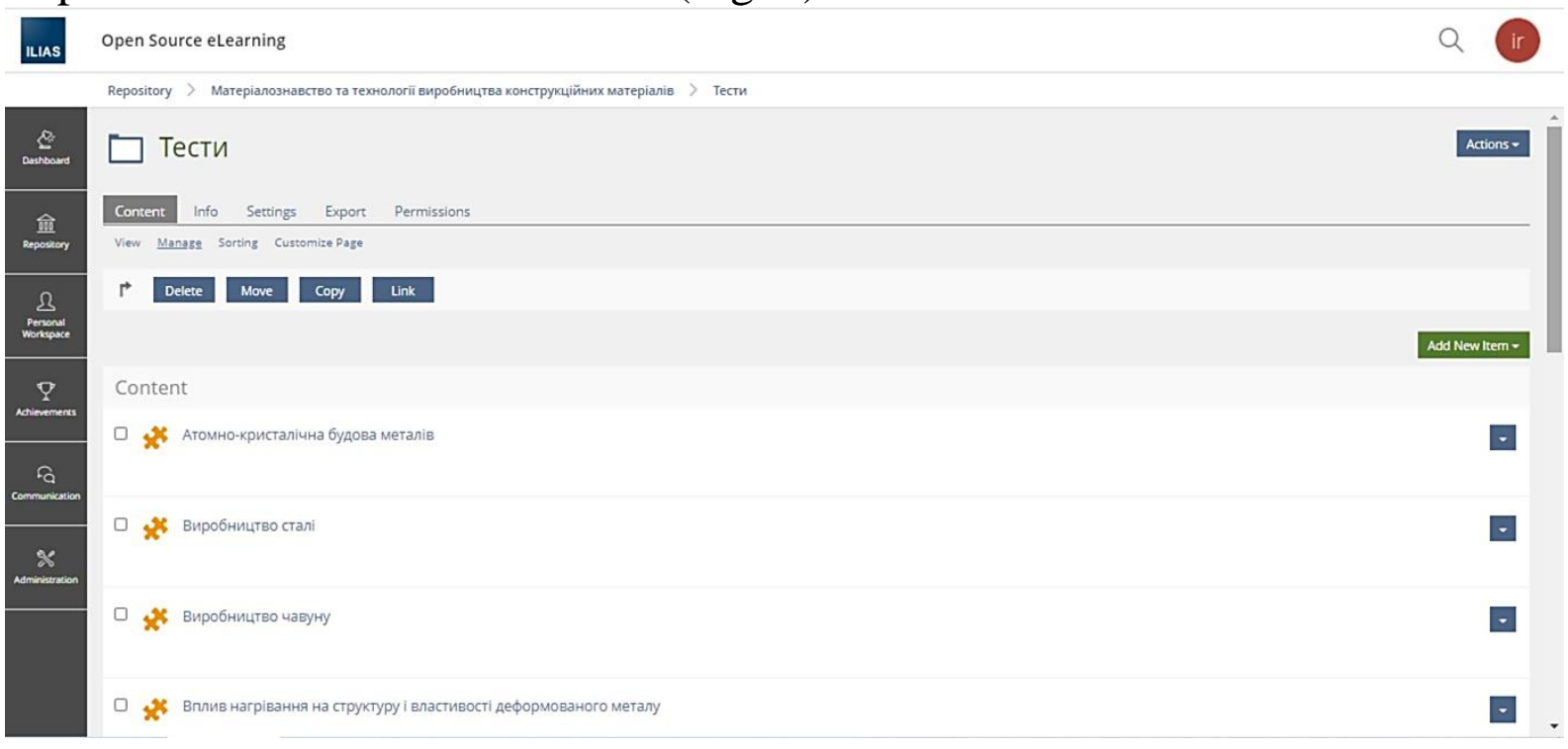

Figure 3 Tests Content

On the test start page, the system will generate a sequence of different types of questions after pressing the «Start Test» button. The test in ILIAS is an ordered sequence of questions. Depending on the type of question, one or more of the suggested options are chosen or an answer is entered from the keyboard.

The testing process consists of selecting the correct answer and confirming it by pressing «Next» (Fig. 4). When moving on to the last question, the «End Test» button appears.

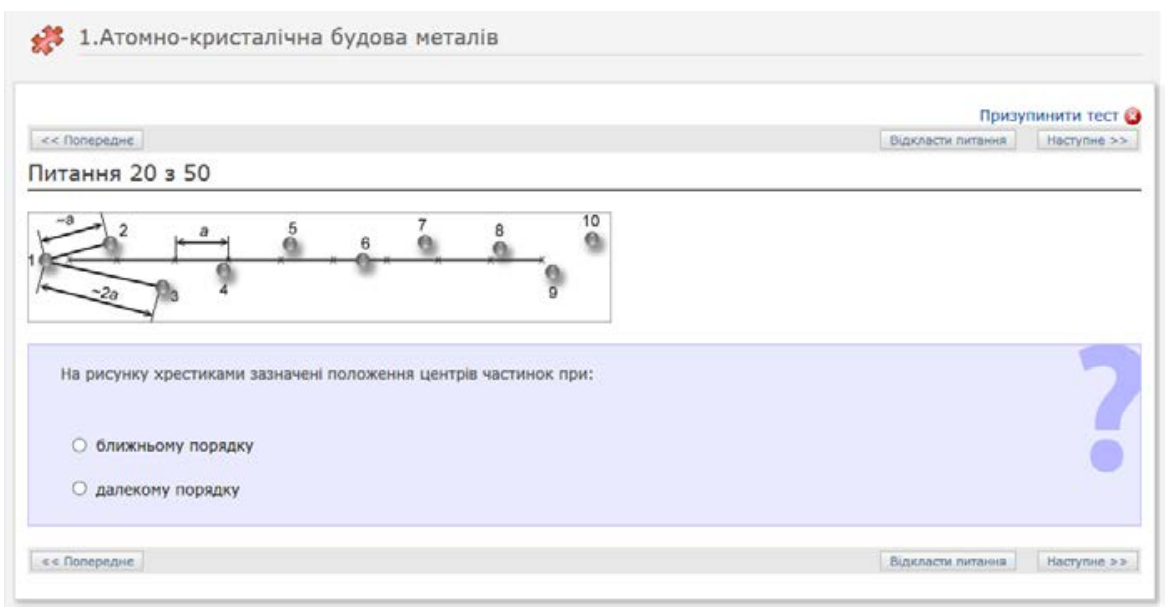

Figure 4 An Example of the Atomic Crystal Structure of Metals Test Page 
If time limits for the current attempt (the teacher sets a time limit depending on the difficulty of the questions) are enabled when taking a test, a timer appears with a countdown to the end of the test.

The «Postpone Question» function allows you to postpone the current question to the end of the test and you can return to the previous question by pressing the «Previous» button. Normally a random sequence of questions and answer choices is generated for each attempt. You can pause the test without completing the current attempt by pressing the «pause test» button. The teacher can also activate additional functions for students, primarily focused on independent learning, in particular:

- $\quad$ the «Show results» button displays the results of the assessment of the question that has been answered;

- the «Hint» button gives short additional information;

- the «Feedback» button displays a detailed assessment with appropriate methodological guidance depending on the answer option chosen (correct, incorrect, partial, etc.).

- The «Solution Suggested» button will direct you to a training module, section, page or other training item which can be used to find the correct answer.

When the teacher has set a specific grading scale, a grade on a point scale is displayed (Fig. 5). In addition, information is obtained on the total number of correct answers, the ratio of the maximum possible score to the achieved score.

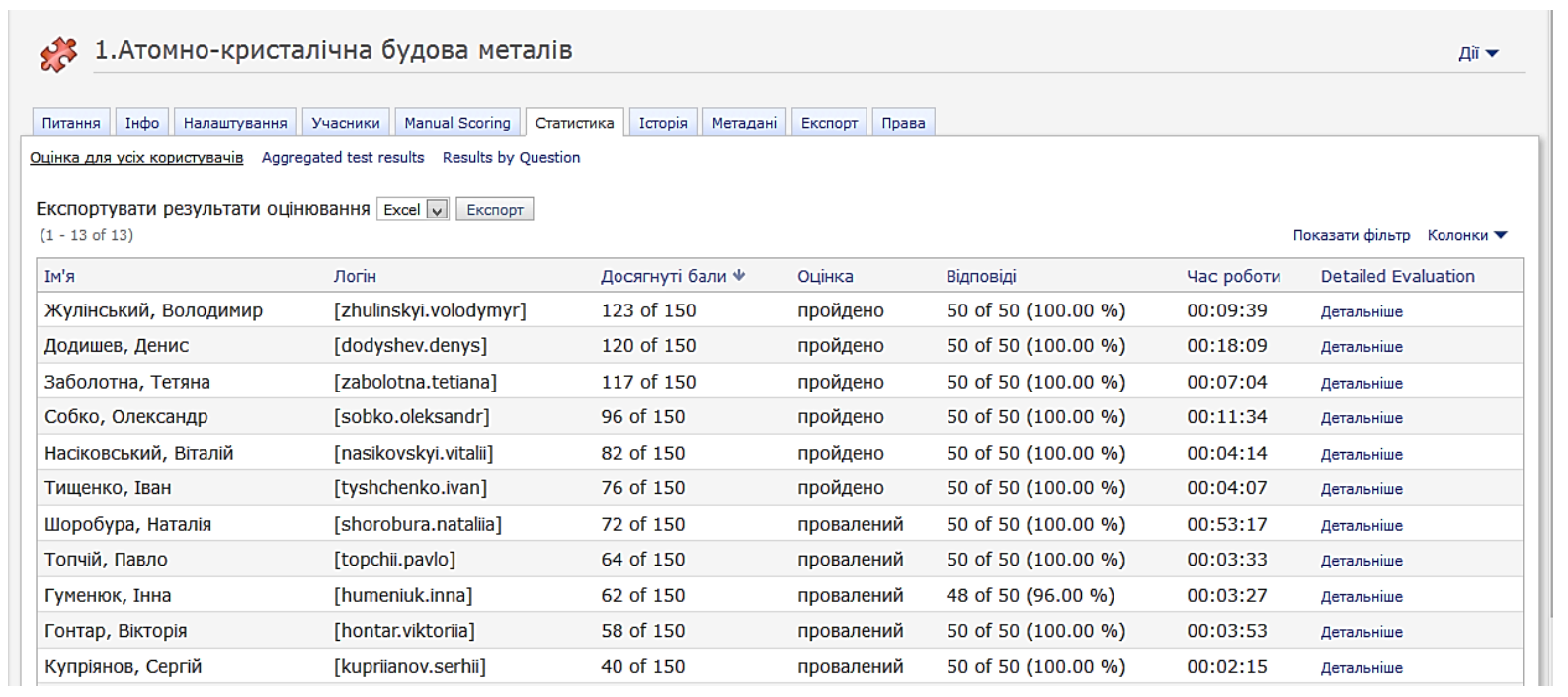

Figure 5 Fragment of the Teacher's Page with Test Results

In addition to general information on test results, detailed results for each student and specific questions can be shown (Fig. 6). 


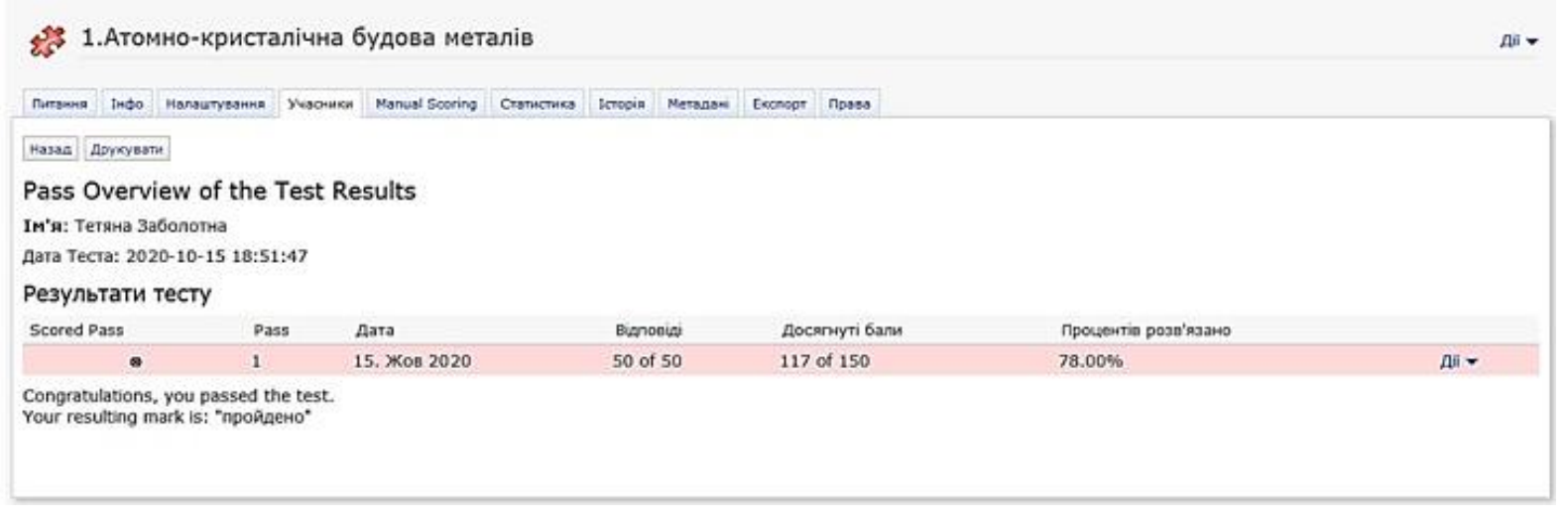

Figure 6 The Result of the Test as Seen by the Student

According to our observations, independent work is no longer a formal element in the holistic pedagogical process only when students perceive it as an essential element of their own development. For this purpose, we built a system of tasks so that to encourage a future specialist to self-promote information and professional activity in the system "information-knowledge-information".

\section{Conclusions}

The organization of the learning process of special subjects using ICT tools has a direct impact on the content of education. At the same time, the new forms of the learning process can provide the acquisition of qualitatively new professional skills.

The implementation of an automated integrated learning management system has ensured greater productivity, improved the quality of education and efficiency in the development of teaching and learning support compared to traditional methods of work. The integrated system based on ILIAS proved to be flexible and easy to organize and develop comprehensive information and methodological support.

The implementation of computer-based test control in the assessment and self-assessment of general and professional competences of students provides high technological efficiency of control and objectivity of the results, allows using flexible scale of knowledge assessment. Computer-based testing is an effective means of motivating students for systematic active self-study of the course, strengthening individualisation of learning, adapting the educational process to the requirements defined by the European Credit Transfer System (ECTS), the features of credit-module system of the educational process organization. 
Shymkova et al., 2021. Use of Learning Management System Ilias in Teaching Technologies for Intending Teachers of Secondary and Vocational Education

\section{References}

Adams, S., Cummins, M., Davis, A., Freeman, A., Hall Giesinger, C., \& Ananthanarayanan, V. (2017). "NMC Horizon Report: 2017” Higher Education Edition. Austin, Texas: The New Media Consortium. URL: https://www.sconul.ac.uk/sites/default/files/ documents/2017-nmc-horizon-report-he-EN.pdf

Avanesov, V.S. (2002). Kompozicziya testovy'kh zadanij [Composition of test items]. Uchebnaya kniga - Educational book, 3 izd. dop. M.: Czentr testirovaniya (in Russian).

Alabi, T.O., Thaddeus, H. \& Falode, O.C. (2020). Effects of ILIAS Online Learning Platform on Academic Achievement in Educational Technology among University Students' in Nigeria. International Journal of Educational \& Research, 03(09), 13-20.

Brusilovsky, P., \& Miller, P. (1999). Web-based testing for distance education. WebNet'99. ngs of AACE World Conference of the WWW and Internet. Honolulu: HI, 149-154.

Chua, Yan Piaw. (2012). Replacing Paper-based Testing with Computer-based Testing in Assessment: Are we Doing Wrong? Procedia - Social and Behavioral Sciences. Issue 64. 655-664. DOI: 10.1016/j.sbspro.2012.11.077.

Dias, S.B., \& Diniz, J.A. (2014). Towards an enhanced learning management system for blended learning in higher education incorporating dinstinct learners' profiles. Educational Technology \& Society, 17, 307-319.

FHOO. (2020). Competing-report (D 3.2). URL: https://www.iwt-competencies.eu/wpcontent/uploads/2020/07/COMPETING-Report-3.2_230720.pdf

Gatreau, C. (2011). Motivational factors affecting the integration of a learning management system by faculty. The Journal of Educators Online, 8(1).

ILIAS. (n.d.). ILIAS Installations - List of ILIAS installations worldwide. URL: https://docu. ilias.de/ilias.php?ref_id=3444\&tableview_id=9\&cmd=show\&cmdClass=ildclrecordlistg ui\&cmdNode=mh:9l:9q\&baseClass=ilRepositoryGUI

Kuzneczov, V.G. (1999). Konczepcziya razvitiya testovoj tekhnologii kontrolya urovnya obuchennosti studentov v sisteme professional`nogo obrazovaniya Rossii [The concept of development of test technology for monitoring the level of student learning in the vocational education system of Russia]. Testy $v$ obrazovanii: Informaczionny j nauchno-metodicheskij byulleten`s e`lektronny`m prilozheniem - Tests in education, issue 1, 30-45 (in Russian).

Lerner, I.Ya. (1996). Razvivayushhee obuchenie s didakticheskikh pozitsij [Developmental teaching from a didactic position]. Pedagogika - Pedagogy. (No. 2), 7-11 (in Russian).

Majorov, A.N. (1997). Testy`shkol `ny `kh dostizhenij: konstruirovanie, provedenie, ispol zovanie [School achievement tests: design, conduct, use]. SPb.: Obrazovanie i kul`tura (in Russian).

Moiseev, V.B., Usmanov, V.V., Tarantseva, K.R., \& Piatyrublevii, L.H. (2001). Statisticheskyi podkhod k priniatiiu reshenii po rezultatam testirovaniia dlia testov otkrytoi formy [Statistical Approach to Decision Making Based on Testing Results for Open-Form Tests]. Open Education - Otkrytoe obrazovanye, issue 1, 51-57 (in Russian).

Osman, A.A. (2010) Learning Management Systems (LMS): Evaluation Framework. LAP LAMBERT Academic Publishing GmbH \& Co. KG: Saarbrucken, Germany.

Paris Communiqué Paris. (2018). URL: http://ehea.info/Upload/document/ministerial_ declarations/EHEAParis2018_Communique_final_952771.pdf 
Shymkova, I.V. (2012). Avtomatyzovana systema upravlinnia navchanniam yak zasib orhanizatsii samostiinoi navchalno-piznavalnoi diialnosti studentiv u protsesi vyvchennia fakhovykh dystsyplin [Automated learning management system as a means of organizing independent educational and cognitive activities of students in the study of professional disciplines]. Zbiór raportów naukowych. „Postępy $w$ nauce $w$ ostatnich latach. Nowych rozwiazań" - Collection of scientific reports. "Progress in science in recent years. New solutions". Warsaw: Sp. o. o. "Diamondtradingtour", part 3/2, 37-42 (in Ukrainian).

Shymkova, I.V. (2017). Orhanizatsiia samostiinoi navchalno-piznavalnoi diialnosti maibutnikh vchyteliv trudovoho navchannia $\mathrm{v}$ navchanni tekhnolohii vyrobnytstva konstruktsiinykh materialiv [Organization of independent educational and cognitive activity of future teachers of labour education in teaching technologies of production of construction materials]. Naukovyi chasopys Natsionalnoho pedahohichnoho universytetu imeni M. P. Drahomanova. Problemy trudovoi ta profesiinoi pidhotovky Problems of labor and professional training. Kyiv: Vyd-vo NPU imeni M.P. Drahomanova, issue 9, № 13, 104-111 (in Ukrainian).

Zajceva, L.V., \& Prokof`eva, N.O. (2002). Problemy komp`yuternoho kontrolya znanij [Problems of computer control of knowledge]. IEEE International Conference on Advanced Learning Technologies (ICALT 2002). Proceedings. Kazan, Tatrstan, Russia. 102-106 (In Russian). 